\title{
Cyanobacterial Diversity of the Northern Polar Ural Mountains
}

\author{
Denis Davydov ${ }^{1,2}$ (1)
}

Citation: Davydov, D.

Cyanobacterial Diversity of the Northern Polar Ural Mountains. Diversity 2021, 13, 607. https:/ / doi.org/10.3390/d13110607

Received: 15 October 2021

Accepted: 19 November 2021

Published: 22 November 2021

Publisher's Note: MDPI stays neutral with regard to jurisdictional claims in published maps and institutional affiliations.

Copyright: (C) 2021 by the author. Licensee MDPI, Basel, Switzerland. This article is an open access article distributed under the terms and conditions of the Creative Commons Attribution (CC BY) license (https:// creativecommons.org/licenses/by/ $4.0 /)$.
1 Polar Alpine Botanical Garden Institute Kola SC RAS, Botanical Garden, 184256 Kirovsk, Russia; d_disa@mail.ru; Tel.: +7-9211-758-820

2 Institute of the Industrial Ecology Problems of the North of the Kola Science Center of RAS, 14a Fersman's st., 184209 Apatity, Russia

\begin{abstract}
This study provides new results from an inventory of cyanobacterial species from the Northern Polar Ural Mountains. The article also compiles all existing published data on the cyanobacterial diversity of the region. This ecoregion is located in a unique geographical position in the transition between the sub-Arctic and low Arctic zones and heterogeneous natural conditions. Likely, the unexplored biodiversity of this area's terrestrial cyanobacteria is high. In total, 52 localities were studied, with 232 samples collected. Cyanobacterial samples were studied under a light microscope. Species were identified based on morphological characteristics only. A total of 93 species of cyanobacteria were identified in different habitats; 70 species were found on wet rocks, 35 on the shores of water bodies, 27 in slow streams, and 21 on waterfalls. In total, 37 species are reported as part of the Ural flora for the first time, while three species (Chroococcus ercegovicii, Gloeocapsopsis cyanea, Gloeothece tepidariorum) were detected in Russian territory for the first time. The composition of the cyanobacterial flora of the Polar Urals was compared with the flora of the nearby Arctic and sub-Arctic regions. According to the Sorensen similarity index, the Polar Urals' flora is more like the flora of Nenets Autonomous Okrug.
\end{abstract}

Keywords: diversity; cyanobacteria; Polar Urals; Arctic; distribution

\section{Introduction}

Cyanobacteria make up an important component of extreme Arctic environments. They are of fundamental ecological importance since they contribute to both carbon and nitrogen fixation and are often the dominant primary producers in polar ecosystems. Local cyanobacterial flora are sources of information for nature conservation and environmental monitoring. The diversity and distribution of cyanobacteria are still poorly understood in Northern Russia [1].

The study of cyanobacterial diversity is important to consider different microbial distribution patterns [2]. Morphological and anatomy traits are the main criteria for classifying and identifying cyanobacteria. Recent studies have shown that traditional cyanobacterial "morphospecies" are comprised of different taxonomic species [3-7]. On the other hand, many cyanobacterial taxa do not have gene sequence data. Widespread taxa, such as Dichothrix, Petalonema, and Stigonema, are cultivation-resistant genera. Only a small number of genotypes of typical terrestrial cyanobacteria, such as Chroococcus, Gloeocapsa, and Gloeocapsopsis, were evaluated. Most of the data about biodiversity accumulated in previous studies are based on the morphological method of identification. Obviously, reliable morphological species identification of the Arctic's cyanobacteria is challenging. An integrative approach including 16S rRNA gene and ITS sequence data, detailed observations of various life stages, correct comparative ecological studies, and geographic distribution could obtain the most accurate estimation of diversity. That method, as a tool for next generation sequencing (NGS), will be able to uncover cyanobacterial diversity of natural assemblages. Currently, NGS results provide a high number of abstract organizational taxonomic units [4]. Unidentified units cannot be used for ecological or geographical 
studies. Perhaps in transition, the use of "morphospecies" as surrogate units would be helpful in biodiversity surveys.

The Urals are situated on the border of Europe and Asia and are characterized by unique natural conditions. The Polar Urals, located north of the Arctic Circle, are the northernmost part of the giant Urals Ridge.

The exploration of the Polar Urals Mountains' cyanobacteria began in the 20th century. The first records were published by Voronichin [8]. A significant proportion of the diversity data have been obtained in recent years [9-18].

The total known cyanobacterial diversity of the Polar Urals was 156 species before our work. In previous studies, mostly aquatic ecotopes and soil biocrusts were investigated. At the same time, cyanobacteria of terrestrial habitats in the Polar Urals remain insufficiently researched. The species distribution in the territory of the mountain massif has not been revealed. The floristic relationship between the cyanobacterial flora of the Polar Urals and the flora in other Arctic and sub-Arctic regions has not been analyzed yet. The purpose of this study was to conduct a field exploration of the northern Urals of the Polar region and to determine the biodiversity of cyanobacteria.

\section{Characteristics of the Study Area}

The investigated area is situated on the northern part of the Polar Urals (Figure 1). The landscape of the Polar Urals is characterized by glacial landforms such as cirques, U-shaped valleys, and lakes. Short ridges are situated within a meridional plane and the river valleys pass athwart them. The highest peaks reach 900-1400 m above sea level (m a.s.1.), whereas the trunk valley floors are only 200-300 $\mathrm{m}$ a.s.l. The width of the mountain range in the study area is about $125 \mathrm{~km}$.

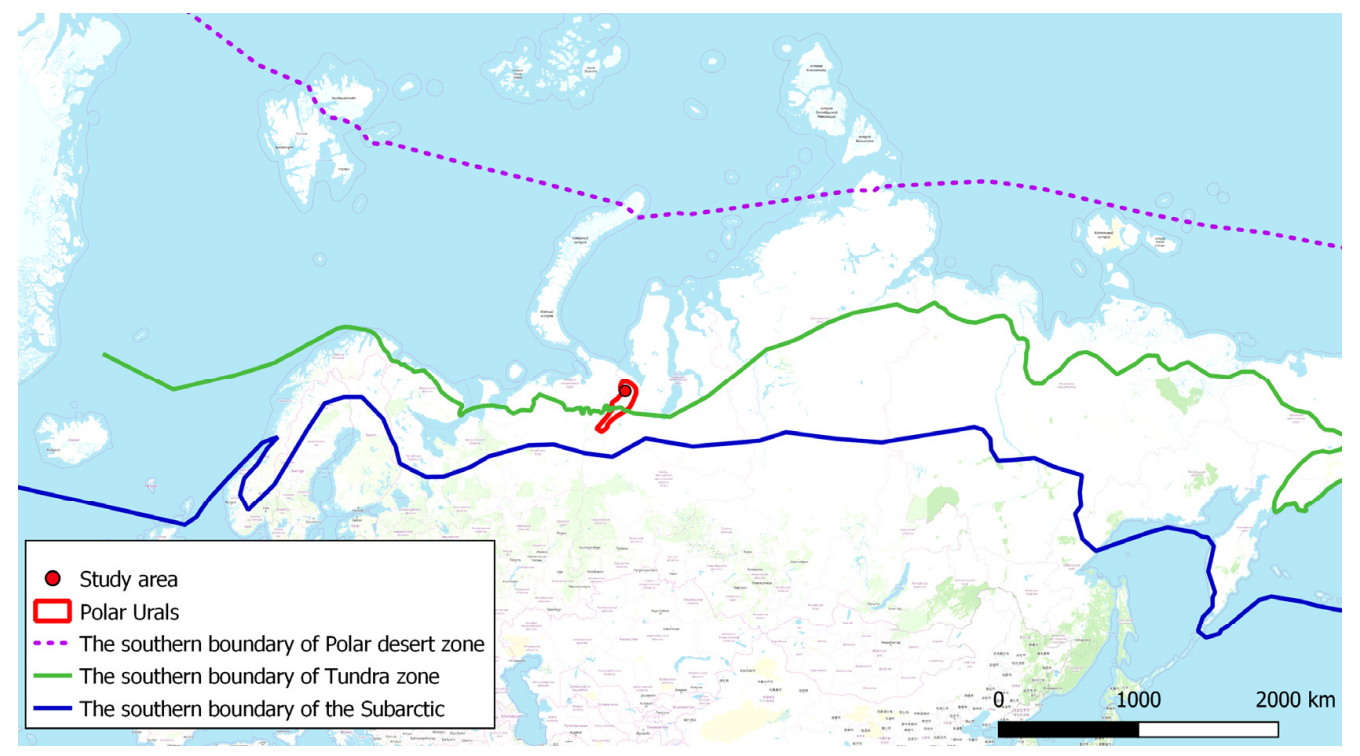

Figure 1. Map showing study area (red circle) in the Polar Urals.

The western slope is steeper and dissected by rivers and streams much more than the eastern one [19]. Along with plateau-like peaks, ridges with typical alpine relief forms are widely developed here. The highest of them in the northern part is the Ochenyrd ridge. There are a few cirque glaciers on the northern exposure slopes [20].

The northern part of the Polar Urals is situated within a field of limestones with shale and trachybasalts [21].

The climate of the area is cold and continental with permafrost and a mean summer temperature range between 10 and $13^{\circ} \mathrm{C}$ in the adjacent lowlands. The average annual temperature in different areas ranges from -6 to $-9{ }^{\circ} \mathrm{C}$. The period with temperatures above $0{ }^{\circ} \mathrm{C}$ lasts about 60 days from June 21 to August 21 [22]. Precipitation is uneven on 
the macroslope. The annual precipitation on the western macroslope is up to $1500 \mathrm{~mm}$. On the eastern macroslope, it is $600-800 \mathrm{~mm}$.

The northern part of the Polar Urals is entirely located in the zonal tundra. The mountains have explicit altitudinal vegetation belts. That altitudinal zonation is composed of two belts: the lower parts of the mountain slopes up to 500-600 m a.s.l. are occupied by the mountain tundra belt, the higher area is the stony barren (golets) belt [23].

\section{Materials and Methods}

In 2019, expeditions studied a total of 52 localities (Figure 2, Table 1) and 232 samples were collected. Altogether, 10 types of habitats were distinguished: (i) bottoms of lakes, (ii) pools in tundra, (iii) fast running streams, (iv) waterfalls, (v) slow running streams in tundra, (vi) shores of a water bodies, (vii) outliers, (viii) wet soils, (ix) wet and dripping rocks, and $(\mathrm{x})$ bare patches of permafrost stock.

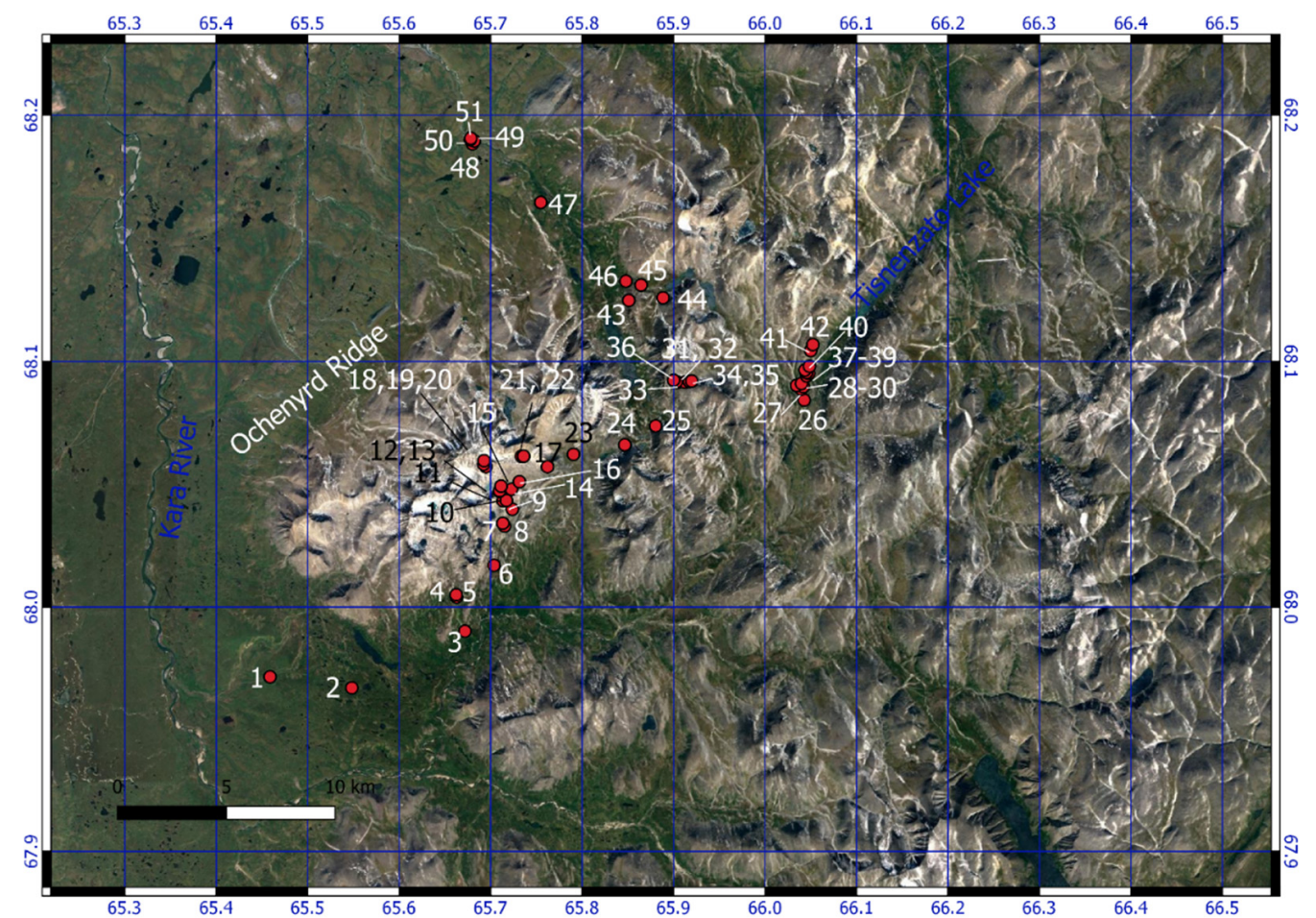

Figure 2. Position of sample plots in the northern Polar Urals Mountains, numbers of sample plots as outlined in Table 1.

The species identification was based only on morphological features. The collected natural samples were observed under an AxioScope A1@ (Carl Zeiss Microscopy GmbH, Germany) light microscope with the Nomarski interference contrast and ProgRes Speed XT Core 3๑ camera (Jenoptik $\odot$, Germany). AxioVision $\odot$ software (Carl Zeiss Microscopy $\mathrm{GmbH}$, Germany) was used for measuring morphology. The species identification was performed following modern manuals [24-26]. New taxonomic revisions have been taken into account also [6]. 
Table 1. Description of study site.

\begin{tabular}{|c|c|c|c|c|}
\hline No $^{1}$ & Latitude $\mathbf{N}$ & Longitude E & Elevation (m a.s.1.) & Description of Study Site \\
\hline 1 & 67.9715 & 65.45875 & 153 & Gnettyvis river, a pebble on the bottom. \\
\hline 2 & 67.967 & 65.54814 & 196 & Gnetty lake area. On the dirt road. The biological soil crust. \\
\hline 3 & 67.99013 & 65.67176 & 218 & $\begin{array}{l}\text { Ochenyrd ridge. Bolshaya Kara river valley. A fast stream } \\
\text { near a waterfall. }\end{array}$ \\
\hline 4 & 68.00411 & 65.66261 & 365 & $\begin{array}{l}\text { Ochenyrd ridge. Bolshaya Kara river valley. On the SW } \\
\text { exposure wall of an outlier. }\end{array}$ \\
\hline 5 & 68.005 & 65.66225 & 351 & Ibid. On the $\mathrm{W}$ exposure wall of an outlier. \\
\hline 6 & 68.01703 & 65.70358 & 365 & $\begin{array}{l}\text { Ochenyrd ridge. On the bottom of a small lake at the upper } \\
\text { part of a pass. }\end{array}$ \\
\hline 7 & 68.03303 & 65.71507 & 451 & Ochenyrd ridge. On the shore of a small lake. \\
\hline 8 & 68.03416 & 65.71313 & 463 & $\begin{array}{l}\text { Ochenyrd ridge. The lake is near a glacier. The fast stream, a } \\
\text { pebble on the bottom. }\end{array}$ \\
\hline 9 & 68.03989 & 65.72366 & 510 & $\begin{array}{l}\text { Ochenyrd ridge. The upper part of a pass, a small slow } \\
\text { stream, on a boulder. }\end{array}$ \\
\hline 10 & 68.04331 & 65.71349 & 654 & $\begin{array}{l}\text { Ochenyrd ridge. An unnamed mountain, } \mathrm{N} \text { exposure slope. } \\
\text { Near snow patch, a bare permafrost ground polygon. }\end{array}$ \\
\hline 11 & 68.04346 & 65.71719 & 638 & $\begin{array}{l}\text { Ochenyrd ridge. An unnamed mountain, N exposure slope. } \\
\text { On the jasper outlier. }\end{array}$ \\
\hline 12 & 68.04728 & 65.70953 & 574 & Ibid. On a wet rock. \\
\hline 13 & 68.04742 & 65.70971 & 558 & Ibid. On a small slow stream, on a pebble. \\
\hline 14 & 68.04803 & 65.72273 & 477 & $\begin{array}{l}\text { Ochenyrd ridge. A soil crust on the shore of a lake near a } \\
\text { snow patch. }\end{array}$ \\
\hline 15 & 68.04932 & 65.71127 & 498 & Ochenyrd ridge. On a wet wall of an outlier stone. \\
\hline 16 & 68.05112 & 65.73135 & 479 & $\begin{array}{l}\text { Ochenyrd ridge. Morennyy (Moraine) stream valley. The } \\
\text { bouldering plateau near the lake. On an upper side of a } \\
\text { boulder in a puddle. }\end{array}$ \\
\hline 17 & 68.05721 & 65.76206 & 485 & $\begin{array}{l}\text { Ochenyrd ridge. An unnamed mountain ( } 994.8 \mathrm{~m} \text { a.s.l.). } \\
\text { Rocks of S exposure, on a wet wall. }\end{array}$ \\
\hline 18 & 68.05724 & 65.69468 & 958 & $\begin{array}{l}\text { Ochenyrd ridge. An unnamed mountain (1375 m a.s.l.). } \\
\text { Rocks of E exposure, on a wet wall. }\end{array}$ \\
\hline 19 & 68.05827 & 65.69228 & 1051 & Ibid. On a wet wall. \\
\hline 20 & 68.05968 & 65.69263 & 1161 & Ochenyrd ridge. A wet wall of rock near a waterfall. \\
\hline 21 & 68.06146 & 65.73355 & 567 & $\begin{array}{l}\text { Ochenyrd ridge. S exposure slope of the unnamed mountain } \\
\text { (994 m a.s.l.). On a wet rock. }\end{array}$ \\
\hline 22 & 68.06151 & 65.73597 & 557 & $\begin{array}{l}\text { Ochenyrd ridge. S exposure slope of the unnamed mountain } \\
(994 \mathrm{~m} \text { a.s.l.). A wet rock. On the soil, mosses or rock. }\end{array}$ \\
\hline 23 & 68.06225 & 65.79045 & 424 & Ochenyrd ridge. The slow stream. \\
\hline 24 & 68.06613 & 65.8465 & 361 & $\begin{array}{c}\text { The lake between Limbyatayaha river valley and Ochety } \\
\text { Lake valley. On the shore of the lake. A puddle. }\end{array}$ \\
\hline 25 & 68.07383 & 65.88036 & 367 & Unnamed mountains $1375 \mathrm{~m}$ a.s.l. A wet rock W exposure. \\
\hline 26 & 68.08432 & 66.04273 & 381 & $\begin{array}{l}\text { Tisnenzato lake valley, west shore of the lake. Unnamed } \\
\text { mountain } 830 \mathrm{~m} \text { a.s.l. Kan'onnyy stream gorge. A wet rock } \\
\text { on the E exposure slope. }\end{array}$ \\
\hline 27 & 68.08879 & 66.03936 & 377 & $\begin{array}{l}\text { Tisnenzato lake valley, south shore of the lake. Unnamed } \\
\text { mountain } 830 \mathrm{~m} \text { a.s.l. Kan'onnyy stream gorge. A wet rock } \\
\text { on the } S \text { exposure slope. }\end{array}$ \\
\hline
\end{tabular}


Table 1. Cont.

\begin{tabular}{|c|c|c|c|c|}
\hline No ${ }^{1}$ & Latitude $\mathbf{N}$ & Longitude E & Elevation (m a.s.1.) & Description of Study Site \\
\hline 28 & 68.08981 & 66.04167 & 381 & Ibid. On the rock. \\
\hline 29 & 68.09029 & 66.03429 & 381 & Ibid. On the rock. \\
\hline 30 & 68.09108 & 66.03974 & 381 & Ibid. On the rock. \\
\hline 31 & 68.09153 & 65.90435 & 700 & $\begin{array}{l}\text { Unnamed mountain, } 832,5 \mathrm{~m} \text { alt. North exposure slope, a } \\
\text { wet wall of rock. }\end{array}$ \\
\hline 32 & 68.0916 & 65.91236 & 669 & $\begin{array}{l}\text { Unnamed mountain, } 832,5 \mathrm{~m} \text { alt. North exposure slope, a } \\
\text { wet wall of rock. }\end{array}$ \\
\hline 33 & 68.09182 & 65.90287 & 704 & Ibid. On a wet wall of rock. \\
\hline 34 & 68.09187 & 65.91724 & 669 & Ibid. A slow stream, on a wet rock. \\
\hline 35 & 68.09208 & 65.91968 & 650 & Ibid. \\
\hline 36 & 68.09241 & 65.89986 & 732 & Ibid. A wet wall of rock. \\
\hline 37 & 68.09413 & 66.04542 & 401 & $\begin{array}{l}\text { The gorge on the west shore of Tisnenzato lake. On the NE } \\
\text { exposure rock of the outlier. }\end{array}$ \\
\hline 38 & 68.09522 & 66.04769 & 404 & $\begin{array}{l}\text { Tisnenzato Lake valley, west shore of the lake. Unnamed } \\
\text { mountain } 830 \mathrm{~m} \text { a.s.l. The E exposure slope. The S exposure } \\
\text { rock. On the soil. }\end{array}$ \\
\hline 39 & 68.09551 & 66.04517 & 415 & $\begin{array}{c}\text { The gorge on the west shore of Tisnenzato lake. On the E } \\
\text { exposure rock of the outlier. }\end{array}$ \\
\hline 40 & 68.09811 & 66.04853 & 446 & $\begin{array}{l}\text { Tisnenzato lake valley, west shore of the lake. Unnamed } \\
\text { mountain } 830 \mathrm{~m} \text { a.s.l. The E exposure slope. The N exposure } \\
\text { rock. On the soil. }\end{array}$ \\
\hline 41 & 68.10442 & 66.04979 & 512 & $\begin{array}{l}\text { Ibid. Dryas octopetala assemblage tundra. A small slow } \\
\text { stream. On the soil. }\end{array}$ \\
\hline 42 & 68.1069 & 66.05212 & 573 & Ibid. Grass tundra assemblage, biological sols crust. \\
\hline 43 & 68.12484 & 65.851 & 502 & $\begin{array}{l}\text { The unnamed mountain }(1070 \mathrm{~m}) \text {, the slope of the south } \\
\text { exposure. On a wet wall of rock. Mosses. }\end{array}$ \\
\hline 44 & 68.12592 & 65.88839 & 522 & $\begin{array}{l}\text { The southern shore of Sidyayambto lake, the unnamed } \\
\text { mountain, slope of the north exposure. On a wet wall } \\
\text { of rock. }\end{array}$ \\
\hline 45 & 68.13106 & 65.86433 & 395 & $\begin{array}{l}\text { Sidyayambtoso river valley. The waterfall on the river. On a } \\
\text { wet wall of the bank's rock. }\end{array}$ \\
\hline 46 & 68.13265 & 65.84778 & 338 & $\begin{array}{c}\text { Sidyayambtoso river valley. On a dry wall of north exposure } \\
\text { rock. Mosses. }\end{array}$ \\
\hline 47 & 68.16459 & 65.75465 & 224 & $\begin{array}{l}\text { The Ochetyvis valley. The left shore of the Ochetyvis river. } \\
\text { Dry rocks od N exposure. Soil. }\end{array}$ \\
\hline 48 & 68.18832 & 65.68006 & 173 & $\begin{array}{l}\text { Ibid. A stream inflow to the Ochetyvis river the left shore, on } \\
\text { a soil. }\end{array}$ \\
\hline 49 & 68.1895 & 65.68204 & 173 & $\begin{array}{l}\text { The Ochetyvis valley. The right shore of the Ochetyvis river. } \\
\text { Epilithic on the pebble in the puddle on the shore. }\end{array}$ \\
\hline 50 & 68.18995 & 65.67754 & 167 & $\begin{array}{l}\text { The Ochetyvis valley. The left shore of the Ochetyvis river. } \\
\text { On rocks and boulders underwater. Calcareous rock. }\end{array}$ \\
\hline 51 & 68.19059 & 65.67815 & 154 & Ibid. On a wet wall of rock, near water. Calcareous rock. \\
\hline
\end{tabular}

${ }^{1}$ Description of study site. No.-number of locality corresponds to Figure 2.

The storage of samples is provided by the herbarium at the Polar-Alpine Botanical Garden-Institute (KPABG). Information on habitats, description of localities, and photographs are included in the CRIS database (http:/ / kpabg.ru/cyanopro/, accessed on 1 October 2021) [27,28]. That information system and the GBIF (http:/ / gbif.org, accessed on 
1 October 2021) portal were used for the analysis of species distribution in the Arctic and the sub-Arctic. QGIS (GNU General Public License) software was used for maps creation.

The frequency of species occurrence (constancy) was calculated by the formula [29]: $B=(a / A) \times 100 \%$, where $B$ is the species occurrence, $a$ is the number of samples containing this taxon, and $\mathrm{A}$ is the total number of samples.

The similarity of local flora was determined with the Sørensen index (KS) (weighted pair group method using arithmetic averaging) in the program module, ExelToR [30], which used as a plugin for Microsoft Excel@.

$K S=\frac{2 \mathrm{a}}{(2 \mathrm{a}+\mathrm{b}+\mathrm{c})}$, where $\mathrm{a}-$ number of species common to both sets, $\mathrm{b}-$ number of species unique to the first set, $c-$ number of species unique to the set.

\section{Results and Discussion}

A summary of cyanobacterial species found in the northern Polar Ural Mountains is given in Table 2. A total of 93 cyanobacterial taxa were identified across the various habitats of the investigated area. In total 37 species are reported in the Polar Ural flora for the first time.

Table 2. The species composition of Cyanobacteria of the northern Polar Urals Mountains.

\begin{tabular}{|c|c|c|c|}
\hline $\mathbf{N}$ & Species & Number of Loaclities ${ }^{1}$ & The Frequency of Species Occurrence (\%) \\
\hline 1 & Aphanocapsa fusco-lutea Hansg. & $14,21,22$ & 1.3 \\
\hline 2 & ${ }^{*}$ A. fonticola Hansg. ${ }^{2}$ & 45 & 0.5 \\
\hline 3 & A. grevillei (Berk.) Rabenh. & 26 & 0.5 \\
\hline 4 & A. muscicola (Menegh.) Wille & $12,21,25,26,40,48$ & 2.6 \\
\hline 5 & * A. parietina Näg. & $4,12,21,22,26$ & 2.2 \\
\hline 6 & ${ }^{*}$ A. rivularis (Carm.) Rabenh. & $4,22,25,47$ & 1.7 \\
\hline 7 & Aphanocapsa sp. & $\begin{array}{c}8,12,14,17,21,22,25,26,34,35,43 \\
44,47,48,50,51\end{array}$ & 7.0 \\
\hline 8 & * Aphanothece pallida (Kütz.) Rabenh. & 26 & 0.5 \\
\hline 9 & A. saxicola Näg. & $12,14,21,22,25,26,34,42,44$ & 3.9 \\
\hline 10 & A. stagnina (Spreng.) A. Braun & 22 & 0.4 \\
\hline 11 & Aphanothece sp. & 22,48 & 0.9 \\
\hline 12 & $\begin{array}{c}\text { * Calothrix breviarticulata W. West et G. } \\
\text { S. West }\end{array}$ & 4,49 & 0.9 \\
\hline 13 & C. parietina Thur. ex Born. et Flah. & $\begin{array}{l}4,5,10,11,13,14,15,17,20,21,22 \\
25,26,27,29,30,31,32,34,35,38 \\
39,41,42,43,44,45,47,48,50,51\end{array}$ & 18.7 \\
\hline 14 & Chamaesiphon polonicus (Rost.) Hansg. & $\begin{array}{c}8,13,14,20,23,31,32,33,35,36,43 \\
45\end{array}$ & 9.6 \\
\hline 15 & ${ }^{*}$ Chlorogloea purpurea Geitl. & 22 & 0.4 \\
\hline 16 & ${ }^{*}$ Chroococcopsis epiphytica Geitl. & 25 & 0.4 \\
\hline 17 & Chroococcus cohaerens (Bréb.) Näg. & $3,7,20,22,36,43$ & 3.5 \\
\hline 18 & *Ch. ercegovicii Komárek et Anagn. & 44 & 0.4 \\
\hline 19 & *Ch. helveticus Näg. & 44 & 0.4 \\
\hline 20 & Ch. minutus (Kütz.) Näg. & $19,26,45$ & 1.3 \\
\hline 21 & $\begin{array}{l}\text { Ch. minutus (Kütz.) Näg. var. } \\
\text { thermalis Copeland }\end{array}$ & 20 & 0.4 \\
\hline 22 & Ch. pallidus (Näg.) Näg. & $6,7,21,25,26,29,43,44$ & 4.8 \\
\hline 23 & Ch. spelaeus Erceg. & $17,21,44,47$ & 2.6 \\
\hline
\end{tabular}


Table 2. Cont.

\begin{tabular}{|c|c|c|c|}
\hline $\mathbf{N}$ & Species & Number of Loaclities ${ }^{1}$ & The Frequency of Species Occurrence (\%) \\
\hline 24 & Ch. tenax (Kirchn.) Hieron. & $22,26,44$ & 1.3 \\
\hline 25 & Ch. varius A. Braun & $11,14,21,22,34,45,46$ & 5.7 \\
\hline 26 & $\begin{array}{c}\text { Cyanosarcina chroococcoides } \\
\text { (Geitl.) Kováčik }\end{array}$ & 26,47 & 0.9 \\
\hline 27 & Cyanosarcina sp. & 22,44 & 0.9 \\
\hline 28 & Cyanothece aeruginosa (Näg.) Komárek & $12,17,22,23,25,27,28,35$ & 4.8 \\
\hline 29 & $\begin{array}{l}\text { Desmonostoc muscorum (C. Ag. ex } \\
\text { Born. et Flah.) Hrouzek et Ventura }\end{array}$ & 21,22 & 0.9 \\
\hline 30 & $\begin{array}{l}\text { Dichothrix gypsophila (Kütz.) Born. } \\
\text { et Flah. }\end{array}$ & $22,27,43,44,47$ & 3.5 \\
\hline 31 & D. orsiniana (Kütz.) Born. et Flah. & 6 & 0.4 \\
\hline 32 & Fischerella muscicola (Thur.) Gom. & 4,36 & 0.9 \\
\hline 33 & * Gloeocapsa alpina (Näg.) Brand & 44 & 0.4 \\
\hline 34 & G. compacta Kütz. & $22,30,34,35,43,44,47$ & 6.1 \\
\hline 35 & ${ }^{*}$ G. fusco-lutea (Näg.) Kütz. & 29 & 0.4 \\
\hline 36 & * G. kuetzingiana Näg. & $\begin{array}{c}12,14,15,17,18,21,22,25,27,29 \\
34,35,42,43,44\end{array}$ & 10.9 \\
\hline 37 & ${ }^{*}$ G. ralfsii (Harv.) Kütz. & 14 & 0.9 \\
\hline 38 & ${ }^{*}$ G. rupestris Kütz. & 27 & 0.4 \\
\hline 39 & G. sanguinea (C. Ag.) Kütz. & $\begin{array}{c}12,14,15,17,18,21,22,26,27,29 \\
34,35,37,39,43,44,45,46\end{array}$ & 13.0 \\
\hline 40 & G. violascea (Corda) Rabenh. & $\begin{array}{c}5,7,14,15,17,18,19,21,22,25,26 \\
27,29,30,34,39,43,44,45,46,51\end{array}$ & 23.0 \\
\hline 41 & $\begin{array}{l}\text { * Gloeocapsopsis chroococcoides } \\
\text { (Nováček) Komárek }\end{array}$ & 29 & 0.9 \\
\hline 42 & $\begin{array}{c}\text { * G. cyanea (Krieger) Komárek } \\
\text { et Anagn. }\end{array}$ & 44 & 0.4 \\
\hline 43 & G. magma (Bréb.) Komárek et Anagn. & $\begin{array}{c}3,4,5,7,10,11,14,15,16,19,21,22 \\
25,26,29,30,34,35,36,38,39,40 \\
43,45\end{array}$ & 16.1 \\
\hline 44 & $\begin{array}{l}\text { *G. pleurocapsoides (Nováček) } \\
\text { Komárek et Anagn. }\end{array}$ & 43 & 0.4 \\
\hline 45 & Gloeocapsopsis sp. & $31,32,45$ & 1.3 \\
\hline 46 & * Gloeothece confluens Näg. & $25,45,47$ & 1.3 \\
\hline 47 & * G. fusco-lutea Näg. & 44 & 0.4 \\
\hline 48 & ${ }^{*}$ G. heufleri Grunov & 17,44 & 0.9 \\
\hline 49 & ${ }^{*}$ G. palea (Kütz.) Rabenh. & 44 & 0.4 \\
\hline 50 & ${ }^{*}$ G. rupestris (Lyngb.) Born. & 26,29 & 1.3 \\
\hline 51 & ${ }^{*}$ G. tepidariorum (A. Braun) Lagerh. & 27,42 & 1.7 \\
\hline 52 & $\begin{array}{l}\text { * Leptolyngbya } \\
\text { "Albertano } \backslash \text { Kováćik-green" }\end{array}$ & 25 & 0.4 \\
\hline 53 & $\begin{array}{l}\text { Leptolyngbya cf. gracillima (Hansg.) } \\
\text { Anagn. et Komárek }\end{array}$ & $12,13,14,19,21,25,35,44,45,47$ & 5.2 \\
\hline 54 & ${ }^{*}$ L. sieminskae Richt. et Matula & $\begin{array}{c}12,14,15,21,22,27,31,32,34,35 \\
38,43,44,47,51\end{array}$ & 9.6 \\
\hline
\end{tabular}


Table 2. Cont.

\begin{tabular}{|c|c|c|c|}
\hline $\mathbf{N}$ & Species & Number of Loaclities ${ }^{1}$ & The Frequency of Species Occurrence (\%) \\
\hline 55 & Leptolyngbya sp. & $46,48,49,50,51$ & 3.5 \\
\hline 56 & Merismopedia glauca (Ehrenb.) Kütz. & 44 & 0.4 \\
\hline 57 & $\begin{array}{l}\text { Microcoleus autumnalis (Trev. ex Gom.) } \\
\text { Strunecky et al. }\end{array}$ & $\begin{array}{c}7,9,13,19,20,27,33,34,35,41,44 \\
45\end{array}$ & 10.4 \\
\hline 58 & ${ }^{*}$ M. vaginatus Gom. ex Gom. & $\begin{array}{c}10,15,22,27,30,35,38,39,42,43 \\
48,51\end{array}$ & 9.1 \\
\hline 59 & $\begin{array}{l}\text { * Nostoc caeruleum Lyngb. ex Born. et } \\
\text { Flah. }\end{array}$ & $1,17,45,47,48,49,50,51$ & 4.8 \\
\hline 60 & N. commune Vauch. ex Born. et Flah. & $\begin{array}{c}5,7,10,12,14,21,22,25,26,27,35 \\
38,39,41,42,43,44,45,46,47,48 \\
49,51\end{array}$ & 13.9 \\
\hline 61 & $\begin{array}{l}\text { Nostoc paludosum Kütz. ex Born. et } \\
\text { Flah. }\end{array}$ & $4,25,41$ & 1.7 \\
\hline 62 & $\begin{array}{l}\text { Nostoc pruniforme [L.] C. Ag. ex Born. } \\
\text { et Flah. }\end{array}$ & 40 & 0.4 \\
\hline 63 & Nostoc sp. & $2,4,15,22,26,35,44,48$ & 4.8 \\
\hline 64 & Oscillatoria sancta Kütz. ex Gom. & 50,51 & 1.3 \\
\hline 65 & O. tenuis C. Ag. ex Gom. & $12,14,24,26,35,38,44$ & 4.8 \\
\hline 66 & $\begin{array}{l}\text { Petalonema incrustans [Kütz.] } \\
\text { Komárek }\end{array}$ & $\begin{array}{c}14,18,22,26,27,29,34,39,42,43 \\
44,46,47,48,51\end{array}$ & 12.2 \\
\hline 67 & Phormidesmis sp. & $\begin{array}{c}4,7,12,14,16,17,18,20,21,22,25 \\
26,27,29,32,33,34,35,36,43,44 \\
45,46\end{array}$ & 24.3 \\
\hline 68 & $\begin{array}{l}\text { * Phormidiochaete nordstedtii (Born. et } \\
\text { Flah. ex De Toni) Komárek }\end{array}$ & 19,45 & 1.7 \\
\hline 69 & Phormidium ambiguum Gom. & 26 & 0.9 \\
\hline 70 & $\begin{array}{l}\text { * P. kuetzingianum (Kirchn. ex Gom.) } \\
\text { Anagn. et Komárek }\end{array}$ & $36,49,50$ & 2.2 \\
\hline 71 & Phormidium uncinatum Gom. ex Gom. & 12,44 & 0.9 \\
\hline 72 & $\begin{array}{l}\text { * Pseudanabaena minima (G. S. } \\
\text { An) Anagn. }\end{array}$ & 30 & 0.4 \\
\hline 73 & Pseudanabaena sp. & 33,49 & 0.9 \\
\hline 74 & $\begin{array}{l}{ }^{*} \text { Rivularia haematites [DC] C. Ag. ex } \\
\text { Born. et Flah. }\end{array}$ & 49 & 0.4 \\
\hline 75 & * Schizothrix lardacea Gom. & 22 & 0.4 \\
\hline 76 & $\begin{array}{l}\text { Scytonema hofmannii C. Ag. ex Born. } \\
\text { et Flah. }\end{array}$ & 45 & 0.4 \\
\hline 77 & $\begin{array}{l}\text { S. ocellatum [Dillw.] Lyngb. ex Born. } \\
\text { et Flah. }\end{array}$ & 22 & 0.4 \\
\hline 78 & $\begin{array}{l}\text { * Siphononema polonicum } \\
\text { (Raciborski) Geitl. }\end{array}$ & 25,44 & 0.9 \\
\hline 79 & Stenomitos sp. & 35,47 & 0.9 \\
\hline 80 & $\begin{array}{c}\text { Stigonema hormoides [Kütz.] Born. } \\
\text { et Flah. }\end{array}$ & 7 & 0.4 \\
\hline 81 & $\begin{array}{l}\text { S. hormoides [Kütz.] Born. et Flah. var. } \\
\text { subarcticum Böcher }\end{array}$ & 43 & 0.4 \\
\hline
\end{tabular}


Table 2. Cont.

\begin{tabular}{|c|c|c|c|}
\hline $\mathbf{N}$ & Species & Number of Loaclities ${ }^{1}$ & The Frequency of Species Occurrence (\%) \\
\hline 82 & S. informe Kütz. ex Born. et Flah. & $4,22,25,35,43,44,47$ & 4.8 \\
\hline 83 & $\begin{array}{l}\text { S. mamillosum [Lyngb.] C. Ag. ex } \\
\text { Born. et Flah. }\end{array}$ & 45 & 0.9 \\
\hline 84 & $\begin{array}{c}\text { S. minutum [C. Ag.] Hass. ex Born. } \\
\text { et Flah. }\end{array}$ & $\begin{array}{c}4,5,7,13,16,18,19,20,21,22,25 \\
28,29,30,34,35,39,42,45,46\end{array}$ & 19.1 \\
\hline 85 & * S. mirabile B.-Mann. & 17 & 0.4 \\
\hline 86 & $\begin{array}{l}\text { S. ocellatum [Dillw.] Thur. ex Born. } \\
\text { et Flah. }\end{array}$ & $14,15,22,25,36,43$ & 3.0 \\
\hline 87 & $\begin{array}{c}\text { * Symplocastrum friesii [C. Ag.] ex } \\
\text { Kirchn. }\end{array}$ & 2 & 0.4 \\
\hline 88 & $\begin{array}{c}\text { Tolypothrix distorta Kütz. ex Born. } \\
\text { et Flahault }\end{array}$ & $12,13,14,21,22,41,44$ & 3.5 \\
\hline 89 & T. tenuis Kütz. ex Born. et Flah. & $\begin{array}{c}4,7,16,21,22,25,26,30,34,35,41 \\
43,44,45,46,47,48\end{array}$ & 13.0 \\
\hline 90 & Tolypothrix sp. & 51 & 0.4 \\
\hline 91 & $\begin{array}{l}{ }^{*} \text { Trichocoleus delicatulus (W. West et } \\
\text { G.S. West) Anagn. }\end{array}$ & 34 & 0.4 \\
\hline 92 & $\begin{array}{l}{ }^{*} \text { T. sociatus (W. West et G. S. } \\
\text { West) Anagn. }\end{array}$ & 44 & 1.3 \\
\hline 93 & Trichocoleus sp. & 18 & 0.4 \\
\hline
\end{tabular}

${ }^{1}$ Numbers in the column correspond to the numbers of localities in Table 1 and Figure $2 .{ }^{2}$ The species recorded in the Polar Urals flora for the first time are marked with an asterisk.

Additionally, three species were detected in Russian territory for the first time. Chroococcus ercegovicii (Figure 3a) were found in aerophytic habitats of limestone outcrops in Croatia and the Czech Republic (Figure 4). Their population in the Polar Urals grows on a wet wall of rock at a slope of the northern exposure. Perhaps the spatial distribution of this species is linked with the location of calcium rocks.

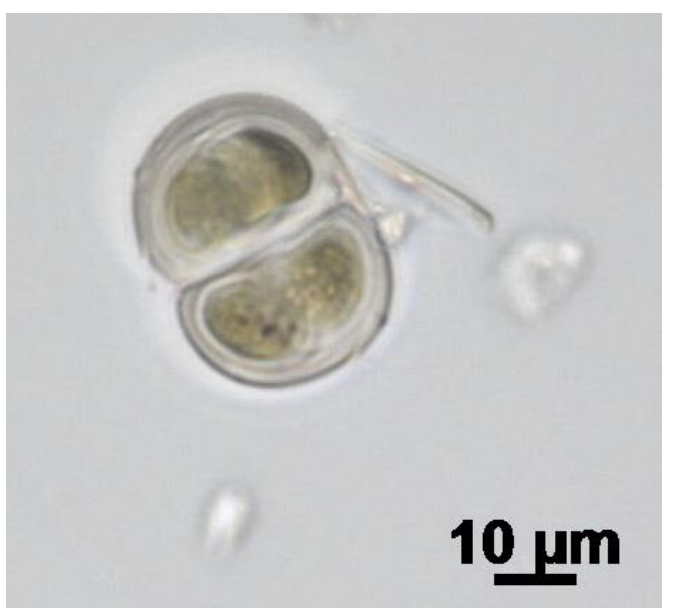

(a)

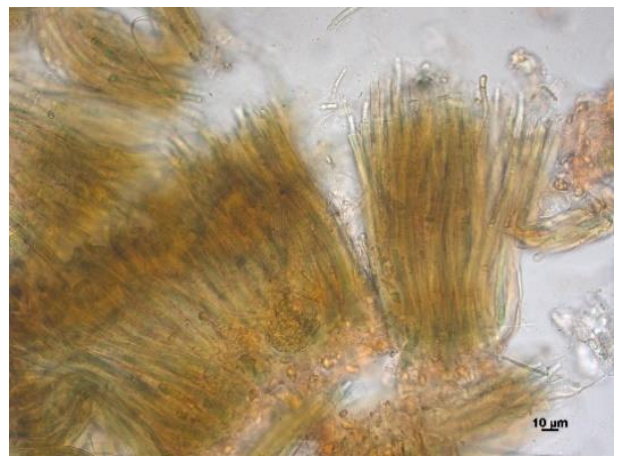

(b)

Figure 3. Rare cyanobacteria species of the Polar Urals flora: (a) Chroococcus ercegovicii, (b) Rivularia haematites. 


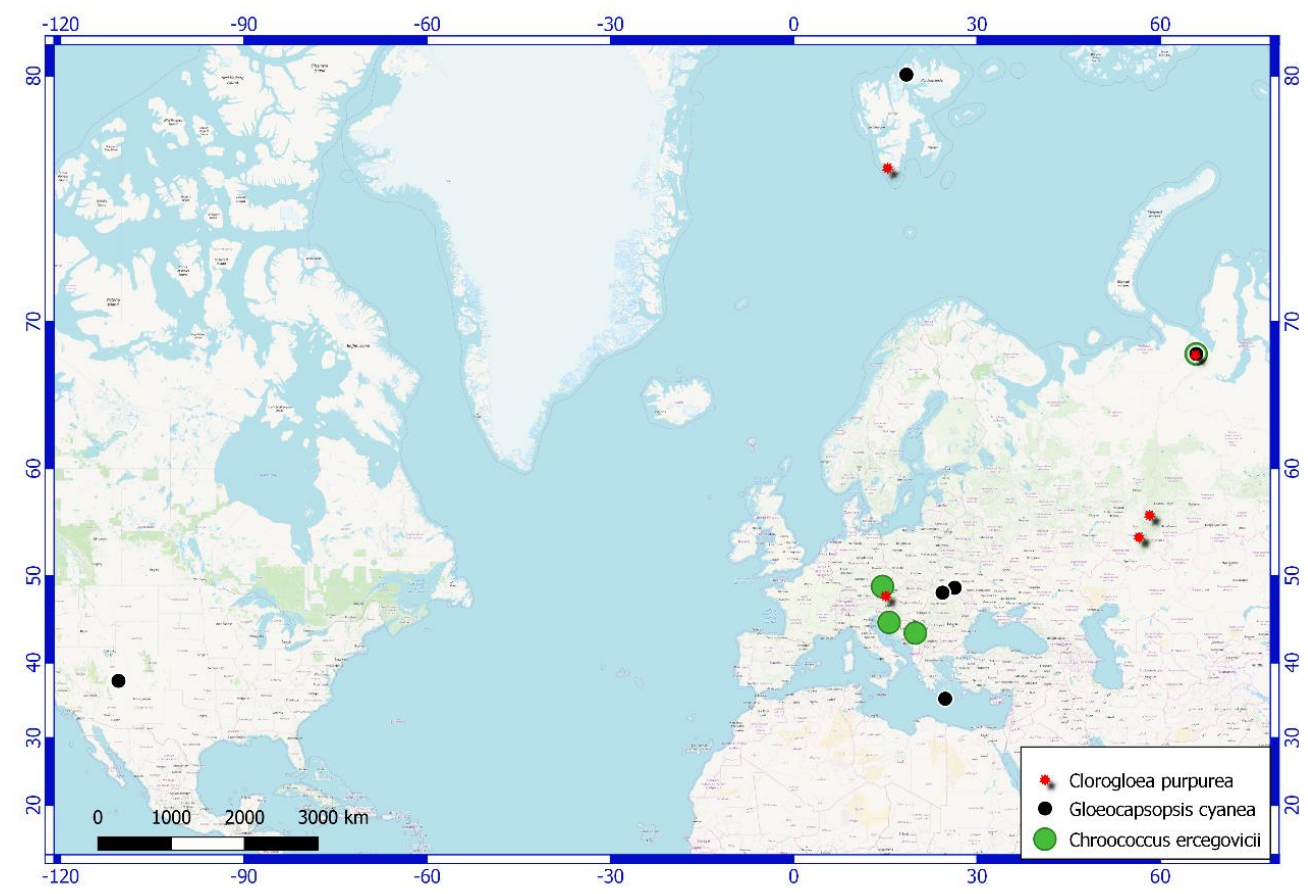

Figure 4. Polar Urals' cyanobacterial flora rare species distribution map.

Gloeocapsopsis cyanea (Figure 4) is another species which was newly discovered in the area. It was identified based on the description of the species from the rock wall of a cave entrance on the island of Crete and was also found in Ukraine, the USA, and the Svalbard archipelago. In the Polar Urals, it was found on a wet wall of rock on a slope of the north exposure.

The third of the new recorded species in Russia is Gloeothece tepidariorum. This taxon is widely distributed. Occurrences of this taxon are recorded in Germany, Scandinavia, the Czech Republic, Greece, the USA, Argentina, Uruguay, and China. The species was found in a typical aerophytic habitat on a wet rock.

An uncommon species is Chlorogloea purpurea. It was identified from a sample from the bottom of a lake in the Austrian Alps [31]. This species was also found in the southern Urals in the Republic of Bashkortostan [32] in a terrestrial habitat (Figure 4). In the Polar Urals, Chlorogloea purpurea grows on a biocrust assemblage on fine earth.

As a result of the flora inventory, 37 taxa of cyanobacteria are reported here for the first time in the Polar Urals. Additionally, a few of them are new records for the Arctic. The distribution of these species in the Arctic and the sub-Arctic is given below.

Aphanocapsa fonticola is a montane species, widespread in Europe's mountains; in the Arctic and sub-Arctic, it is found in Svalbard, Norway, and the Murmansk region. The taxon can also be found in China.

A. parietina is a multizonal species which is widespread in Europe. In the Arctic, the species is found on Svalbard, in the Bolshezemelskaya tundra, on the Taimyr peninsula, and in the Kolyma basin. To the south, it is found in the Murmansk region of the Subpolar Urals.

A. rivularis is an arctic-boreal-montane species; in the Arctic, it is found on Svalbard, in the tundra zone of the Murmansk region, the Bolshezemelskaya tundra, Yakutia, and Alaska.

Aphanothece pallida has a cosmopolitan distribution. In the Arctic, the species was found on the Novaya Zemlya Archipelago and in Alaska. In the sub-Arctic, it occurs in the Murmansk region and Norway. It is also sporadically distributed in the Czech Republic, Germany, France, and the Azores islands.

Calothrix breviarticulata is a species with an unclear distribution, in the Arctic it is sporadically found in Svalbard, while in the sub-Arctic, it is found only in the Murmansk region.

Chlorogloea purpurea is a montane species whose distribution is given above. 
Chroococcopsis epiphytica is also a montane species. This occurrence is the first record of the taxon for the Arctic area. In the sub-Arctic, the species is known to occur in the Murmansk region only. A species with a sporadic montane distribution was also found in the Austrian Alps.

Chroococcus helveticus is a montane species as well. The records of the species in the Arctic are in Svalbard and Novaya Zemlya; in the sub-Arctic, it is found in the Murmansk region and Karelia. The species also occurs in Switzerland and the USA.

Gloeocapsa alpina is a widespread arcto-montane species. It has been found in the Arctic on Svalbard, Franz Josef Land, Severnaya Zemlya archipelago, Eastern European tundra, Yamal, Yakutia, Chukotka, and Ellesmere Island. In the sub-Arctic, it is distributed in Iceland, Norway, Sweden, the Murmansk Region, Karelia, the Subpolar Urals, sub-Arctic Yakutia, and Kamchatka. The global distribution includes the mountains of central Europe and the USA.

G. fusco-lutea is a species with an unclear distribution. In the Arctic, it is found in Svalbard; in the sub-Arctic it occurs in the Murmansk region. It has also been recorded in central and western Europe.

G. kuetzingiana is an arctic-montane species. The taxon is width distributed on the Svalbard archipelago. In the Arctic, it was also found on Ellesmere Island. In the sub-Arctic, it grows in Norway, in the Murmansk region, in the vicinity of Labytnangi town, in the Krasnoyarsk Kray, and in the Magadan region.

G. ralfsii is a montane species. It occurs in Svalbard, Alaska, and Northern Canada in the Arctic.

G. rupestris is an arcto-montane species that was found in Svalbard, the Bolshezemelskaya tundra, Yakutia, and Greenland. In the sub-Arctic, this species occurs in Iceland, the Murmansk region, Karelia, the Subpolar Urals, Krasnoyarsk Kray, and sub-Arctic Yakutia. Gloeocapsopsis chroococcoides is a montane species. In the Arctic, the taxon occurs in Yakutia. In the sub-Arctic, it occurs in the Murmansk region.

G. pleurocapsoides is also a montane species. In the Arctic, it has been recorded on Svalbard. In the sub-Arctic, it is found in Norway and the Murmansk region.

Gloeothece confluens is an arctic-boreal-montane species which is distributed on the Svalbard archipelago as well as the Bolshezemelskaya tundra, and Yakutia. In the subArctic, it was found in the Murmansk region and Subpolar Urals.

Gloeothece fusco-lutea is a species with an unclear distribution. In the Arctic, it is also recorded in Greenland as well as being found in the sub-Arctic Murmansk region.

G. heufleri is a rare species with an unclear distribution. This occurrence is the first record for the Arctic area. In the sub-Arctic, it was found in the Murmansk region.

G. palea is a boreal species. It was rarely recorded in the Arctic-only in Svalbard and the Polar Urals. In the sub-Arctic, this species occurs in the Murmansk region and Krasnoyarsk Kray.

Gloeothece rupestris has a cosmopolitan distribution. In the Arctic, this species is occurs occasionally in Svalbard, in the Bolshezemelskaya tundra, in the vicinity of Labytnangi town, on Severnaya Zemlya archipelago, and in Yakutia. In the sub-Arctic, it is found in Iceland, the Subpolar Urals, the Krasnoyarsk Kray, and the Commander Islands.

Leptolyngbya "Albertano $\backslash$ Kováčik-green" is a taxon with an unclear distribution that, in the Arctic, has been found in the Svalbard only.

L. sieminskae is considered an Arctic species. The taxon has been identified in the Svalbard archipelago and was also found in the Polar Urals.

Microcoleus vaginatus has a cosmopolitan distribution. This taxon could be characterized as width-distributed in the Arctic. It occurs in the following areas: Vize Island, Severnaya Zemlya, Bolshezemelskaya tundra, Ellesmere Island, and Greenland. It is also found in the sub-Arctic in Norway, Sweden, the Murmansk region, and the Pechora river basin. 
Nostoc caeruleum is considered cosmopolitan. In the Arctic, it grows in the Malozemelskaya tundra, the Novaya Zemlya, Yakutia, and the New Siberian Islands. In the sub-Arctic, it occurs in the Murmansk region, Karelia, and the Subpolar Urals.

Phormidiochaete nordstedtii has an arcto-boreal distribution. In the Arctic, this species occurs in Greenland and Svalbard. In the sub-Arctic, it is found in Norway, Sweden, and the Murmansk region.

Phormidium kuetzingianum is a cosmopolitan species. In the Arctic, the species has been recorded in Svalbard, the Malozemelskaya tundra, and Chukotka, while it is found in the Murmansk region and the Subpolar Urals in the sub-Arctic.

Pseudanabaena minima is a species with an unclear distribution, which is found in the Arctic in Svalbard and the sub-Arctic Murmansk region.

Rivularia haematites (Figure 3b) is an arcto-boreal species; in the Arctic it is found in the Canadian Arctic Archipelago, Alaska, Novaya Zemlya, and the Bolshezemelskaya tundra. This taxon is also recorded in the sub-Arctic in the Murmansk region.

Schizothrix lardacea has a cosmopolitan distribution. In the Arctic, the species has been recorded in Svalbard, the Bolshezemelskaya tundra, and the Yamal peninsula. In the sub-Arctic, it is found in the Murmansk region, Krasnoyarsk Kray, Kamchatka, and the Commander Islands.

Siphononema polonicum is a montane species. In the Artic, the species grows in Svalbard and Yakutia; in the sub-Arctic, it occurs in Norway and the Subpolar Urals. In Europe, it is common in the Alps and the Tatras.

Scytonema mirabile is a cosmopolitan species. In the Arctic, it is known to be on Ellesmere Island and the Bolshezemelskaya tundra. In the sub-Arctic, it is found in Norway, Sweden, the Murmansk region, and the Subpolar Urals.

Symplocastrum friesii is also cosmopolitan. The species is widely distributed in the Arctic: Svalbard, Franz Josef Land, the Eastern European tundra, in the vicinity of Labytnangy town, on Yamal, Taimyr, and Severnaya Zemlya. In the sub-Arctic, it is found in the Murmansk region, Karelia, the Subpolar Urals, Krasnodar Kray, Magadan Region, Kamchatka, and the Commander Islands.

Trichocoleus delicatulus is a species with an unclear distribution. The species is found in the flora of Svalbard, though it has not been recorded in the Arctic or in other sub-Arctic locations. The species was also identified in England and in Greece.

T. sociatus has a cosmopolitan distribution. In addition to the Polar Urals, the species is found in the Arctic in the Svalbard Archipelago and on Queen Elizabeth Island (Canadian Arctic Archipelago). It is known to be in the following locations in the sub-Arctic: the Murmansk region, Krasnodar Kray, and the Magadan Region.

The greatest number of species was identified in genera Chroococcus (8 species), Gloeocapsa (8), Aphanocapsa (7), Gloeothece (6), Gloeocapsopsis (5), Nostoc (5), Aphanothece (4), and Leptolyngbya (4). The results suggest that the proportion of poor genera (comprised of 1-2 species) is great. This is typical of other flora in northern areas [33-35].

The common, widespread species in most of the studied habitats are Phormidesmis sp. (the frequency of species occurrence-24.3\%), Gloeocapsa violascea (23\%) (Figure 5a), Stigonema minutum $(19.1 \%)$, Calothrix parietina $(18.7 \%)$, Gloeocapsopsis magma $(16.1 \%)$, Nostoc commune (13.9\%), Gloeocapsa sanguinea (13\%), Tolypothrix tenuis (13\%), Petalonema incrustans $(12.2 \%)$ (Figure 5b), and Gloeocapsa kuetzingiana (10.9\%) (Table 2). Mostly, these are species that both occupy rocky habitats and can grow on fine earth. 


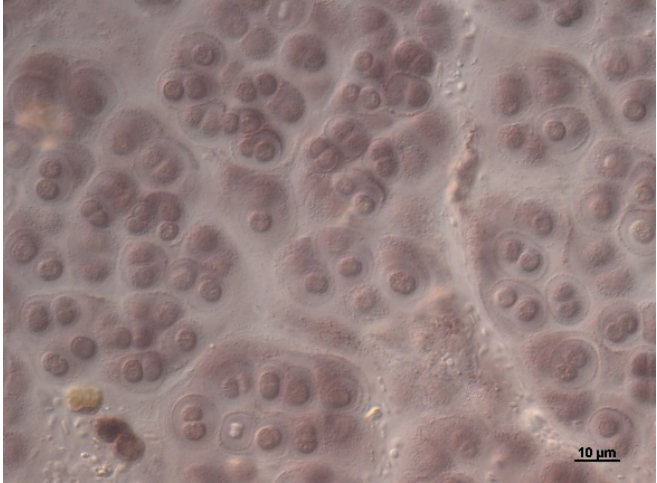

(a)

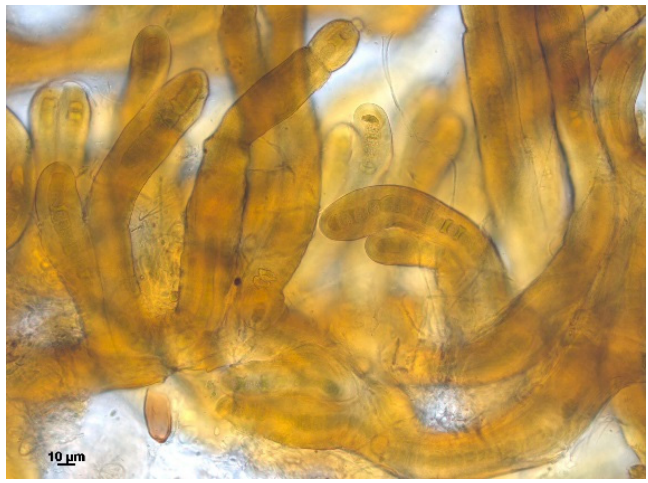

(b)

Figure 5. Widespread cyanobacteria species of the Polar Urals flora: (a) Gloeocapsa violascea; (b) Petalonema incrustans.

The greatest number of species (70) was found on wet rocks and on the shores of lakes and streams (35) (Figure 6). This species distribution by habitat is also typical for the flora of other regions of the Arctic. In the flora of local areas of Svalbard, rocks are most often characterized by high species diversity $[36,37]$. The characteristic feature of the Polar Urals' flora is a lack of cyanobacterial species in typical habitats such as seepages. Usually, the species richness in seepages is secondary to other habitats. Seepages are characterized by stagnant or slowly flowing water from snowmelt. They occur in over-moistened locations on gentle slopes or terraces. This type of habitat, although rare, is found in the Urals. However, this niche is occupied by bryophytes that outcompete cyanobacteria.

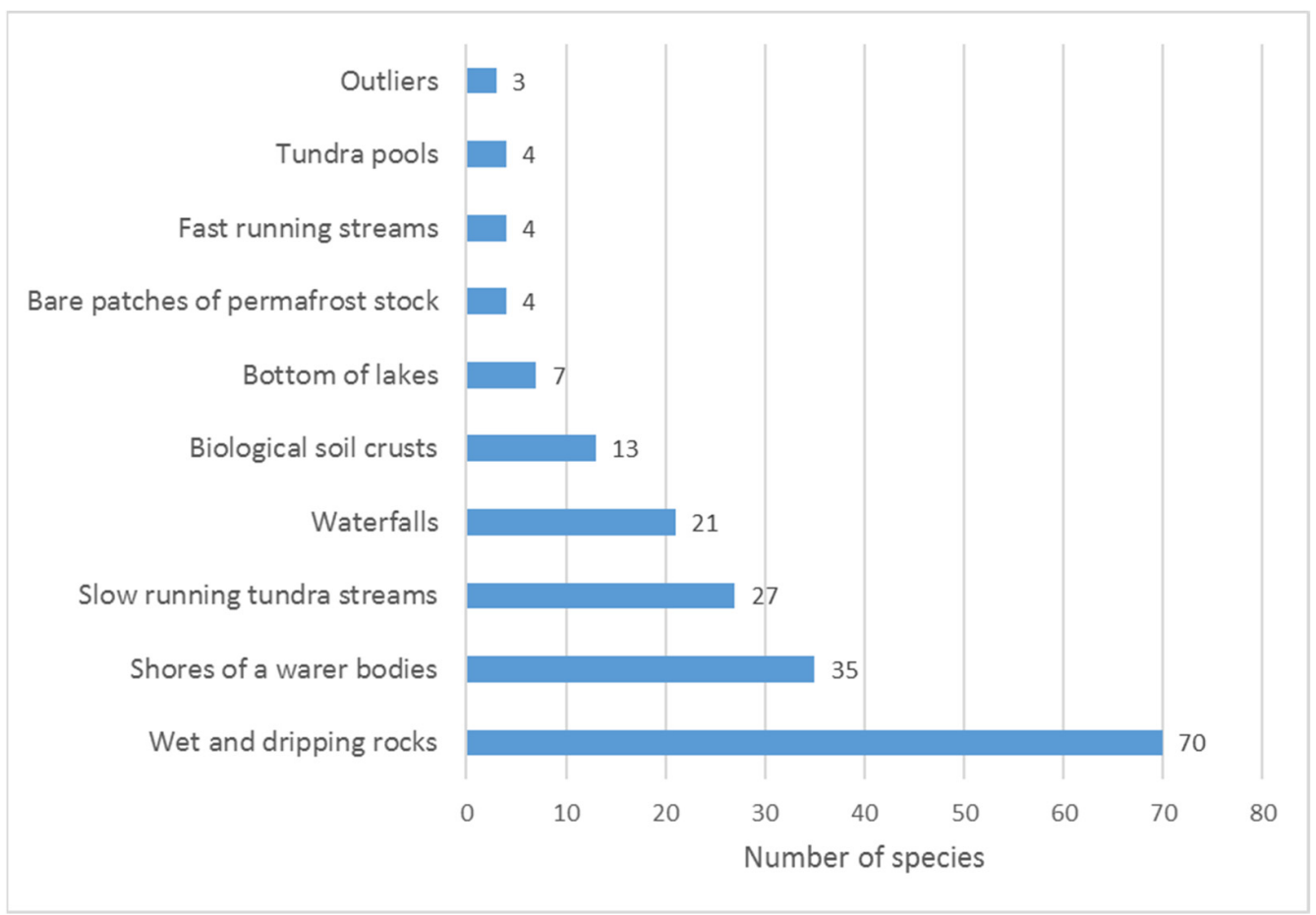

Figure 6. The number of species occurring in the different habitats of the north of the Polar Ural Mountains.

Most of the identified taxa (59 species) are occasionally distributed in the studied area and occur with a frequency of $0.4 \%$ to $1.7 \%$ (Figure 7 ). This is similar to the species distributions of other explored Arctic regions. This peculiarity was noted for local areas of Svalbard [36-40] and the Murmansk region [34]. The reason for the spatial distribution 
of cyanobacterial species in the local area is microenvironmental conditions that favor their growth. Mosaic environmental conditions have the greatest impact on cyanobacterial species composition.

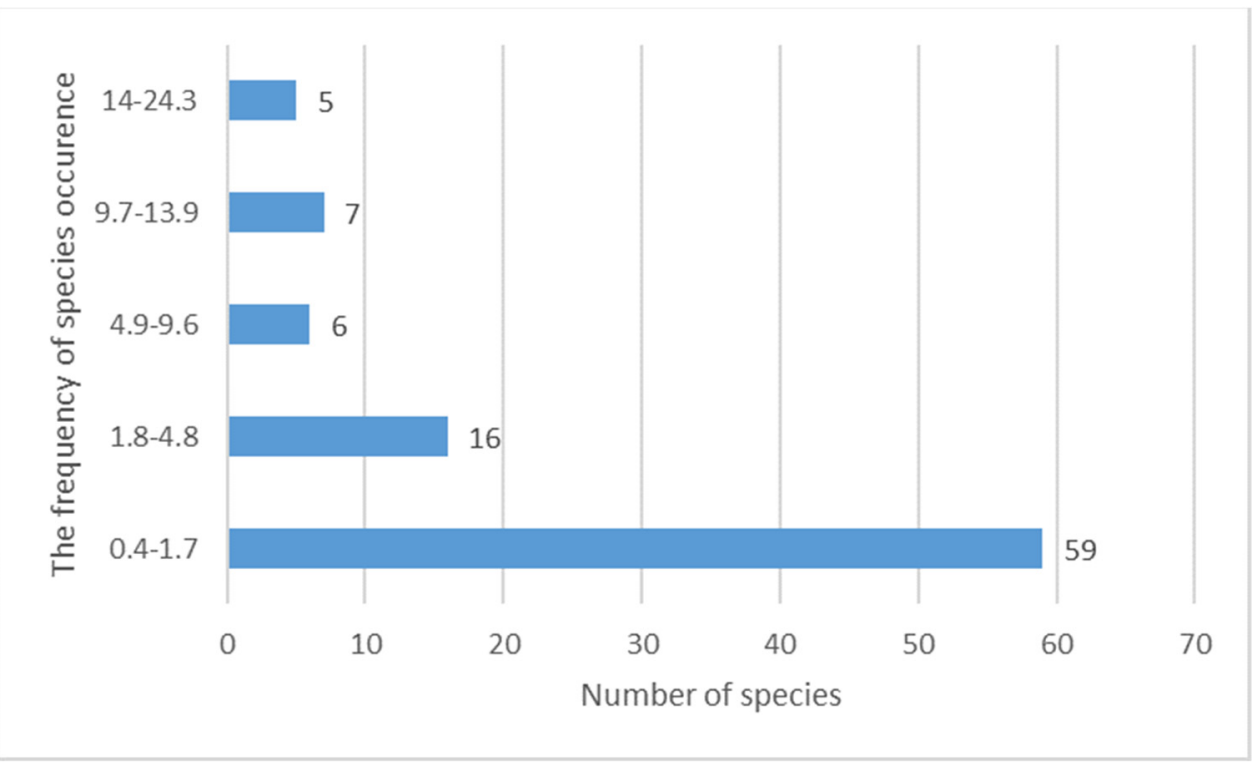

Figure 7. The frequency of species occurrence at the area.

The distribution of species diversity in terms of elevation is a normal distribution (Figure 8). This study has shown that most of the species are found at elevations $400-600 \mathrm{~m}$ above sea level within the mountain tundra belt. The cyanobacterial species diversity decreases during the transition from the mountain tundra belt to the golets belt, reflecting an increase in extreme environmental conditions. The correlation coefficient between the number of species in a given habitat and its height is -0.53 , indicating a significant influence of habitat height on species richness. A notable reduction in the diversity of soil algae in Arctic flora was found approaching mountain peaks [14].

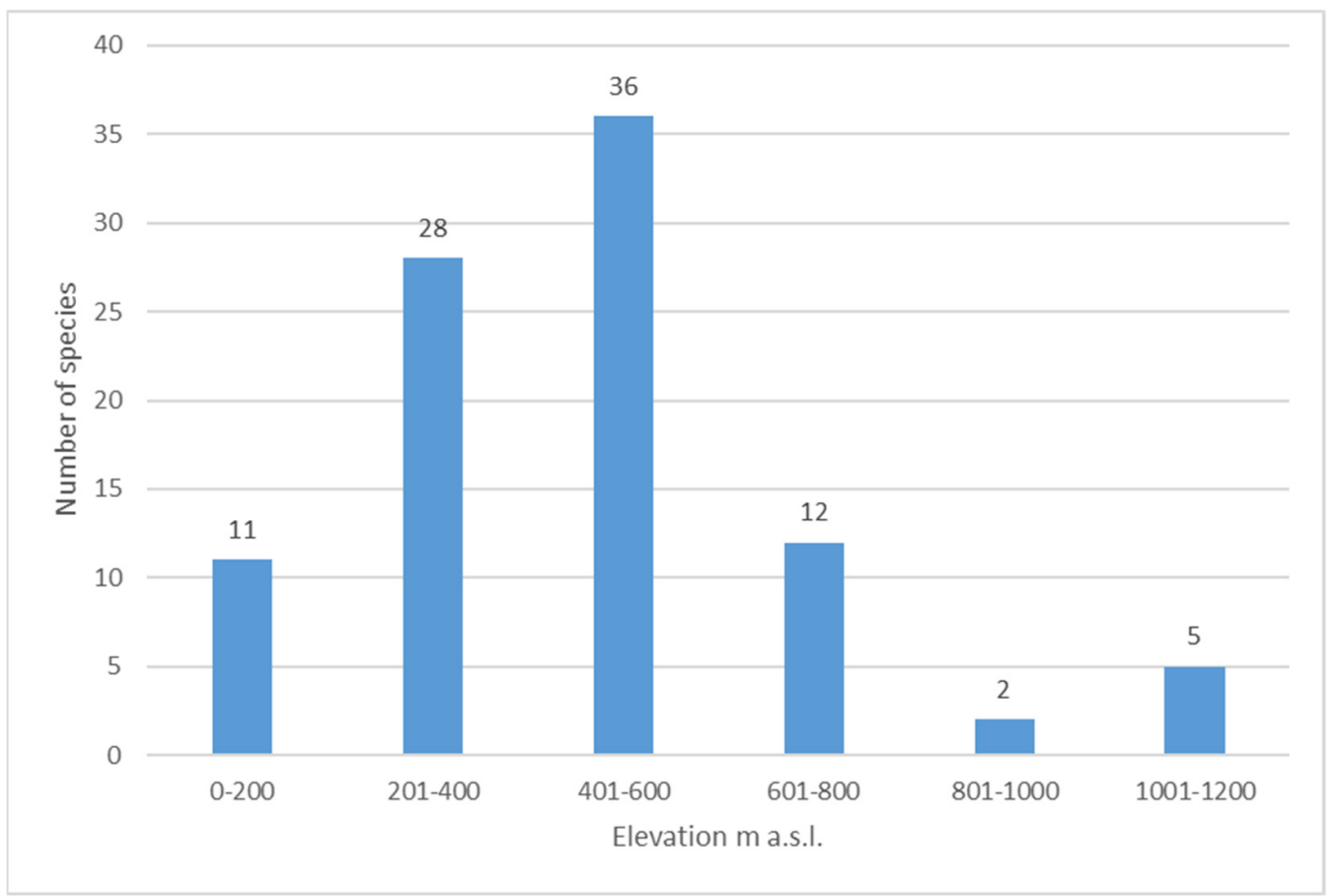

Figure 8. Number of species identified at different altitudes. 
Habitats located in valleys and at the foot of mountains are characterized by a specific floral composition. Species typical for benthic communities at the bottom of rivers (Chamaesiphon minutus, Rivularia haematites) and riverside and coastal rocks have been observed here (Calothrix breviarticulata, Nostoc caeruleum, Phormidium kuetzingianum, Symplocastrum friesii). These are not found in the upper belts.

A middle part of the mountain's slopes $(200-600 \mathrm{~m})$ in the Polar Urals is characterized by the highest cyanobacterial diversity due to both the diversity of habitats and lower pressure of competition from other plants.

Lower species abundance is observed in the upper golets belt. Under mountainous conditions up to 1000 m.a.s.l., species of Leptolyngbya cf. gracillima, Phormidiochaete nordstedtii, Stigonema minutum, Microcoleus autumnalis, and Chroococcus cohaerens are the only cyanobacterial inhabitants. The harsh environment of the golets belt supports fewer species than the mountain tundra belt.

The habitats in the upper belt are characterized by extreme environmental gradients, oscillating temperatures and humidity, and soil dryness. These factors complicate the development of cyanobacteria. The harsh environments are the primary reason for decreased diversity of cyanobacterial assemblages. In addition to the negative impact on the species composition of cyanobacteria, an extreme impact is also shown on the sparse vegetative cover, the decreased role of flowering plants, and significant proportions of projective coverings of lichens and lithophilic mosses [41-43].

We combined our research data with previously published data on the flora of the Polar Urals. Currently, the known cyanobacterial diversity of the Polar Urals is 179 species. Despite the small area of the Polar Urals, this territory is rich in cyanobacterial flora. The flora of this region exceeds that of most of the studied regions of the Eurasian part of the Arctic. It is second only to the flora of Svalbard [44] and the Nenets Autonomous Okrug (AO) [1].

The species richness could be explained by diverse mountain conditions (considerable altitudinal range and diverse landscapes), as well as the relatively low latitude of the Polar Ural region. In addition, an important reason for the high diversity is that the northern part of the Ural region has been well studied compared to other Arctic areas.

According to the Sorensen similarity index, based on the cyanobacterial floral composition, the Polar Urals' flora is more similar to the floras of the nearby regions, Nenets AO (similarity is 54\%) and Svalbard (51\%) (Table 3, Figure 9).

Table 3. Similarity coefficients (\%) of the species composition of the Arctic territories' cyanobacterial floras.

\begin{tabular}{cccccccccc}
\hline & PU & Nen & SPU & SV & NZ & FJL & MRt & MRf & Y \\
\hline Nen & 54 & - & & & & & & \\
\hline SPU & 47 & 57 & - & & & & & \\
\hline SV & 51 & 44 & 45 & - & & & & \\
\hline NZ & 31 & 28 & 32 & 26 & - & & & \\
\hline FJL & 32 & 28 & 37 & 25 & 49 & - & & \\
\hline MRt & 42 & 47 & 46 & 38 & 35 & 29 & - & \\
\hline MRf & 49 & 53 & 47 & 33 & 27 & 24 & 47 & - & \\
\hline Y & 33 & 32 & 29 & 22 & 24 & 31 & 28 & 21 & - \\
\hline T & 46 & 47 & 43 & 33 & 32 & 35 & 38 & 35 & 40 \\
\hline
\end{tabular}

1_Arctic territories: FJL—Franz Josef Land Archipelago, MRf-Murmansk region forest zone, MRt—Murmansk region tundra zone, Nen-Nenets Autonomous Okrug, NZ-Novaya Zemlya Archipelago, PU—Polar Urals, SPU-Subpolar Urals, SV—Svalbard Archipelago, T-Taymyr peninsula, Y-Yamal peninsula. 


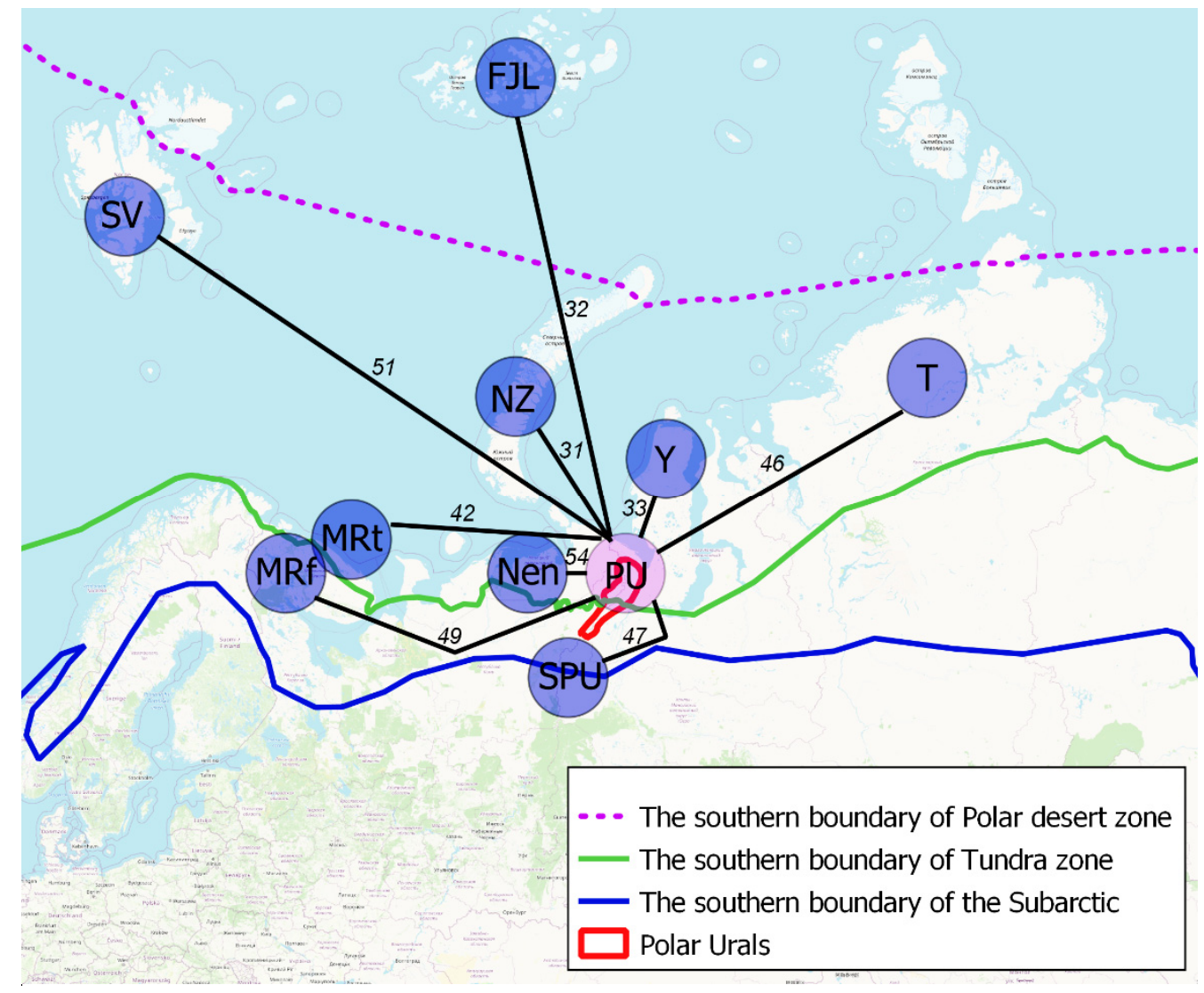

Figure 9. The similarity of cyanobacterial flora of the Polar Urals and some Arctic and sub-Arctic areas. FJL-Franz Josef Land Archipelago, MRt-Murmansk region tundra zone, MRf-Murmansk region forest zone, Nen-Nenets AO, NZ-Novaya Zemlya Archipelago, PU—Polar Urals, SV—Svalbard Archipelago, T-Taymyr peninsula, Y-Yamal peninsula.

A cluster analysis of the flora of the Arctic territories shows that the flora of the nearby regions of the Polar Urals, Subpolar Urals, and Nenets AO, which are close in climatic and geological conditions, are combined into one clade (Figure 10).

The studied flora also has a high similarity to the flora of Svalbard $(51 \%)$, the subArctic part of the Murmansk region, and the Subpolar Urals. This similarity is explained by the similarity of the flora of the mountainous regions, which is characteristic of all the above-mentioned regions, due to relatively widespread species (cosmopolitan and species with a montane distribution). 


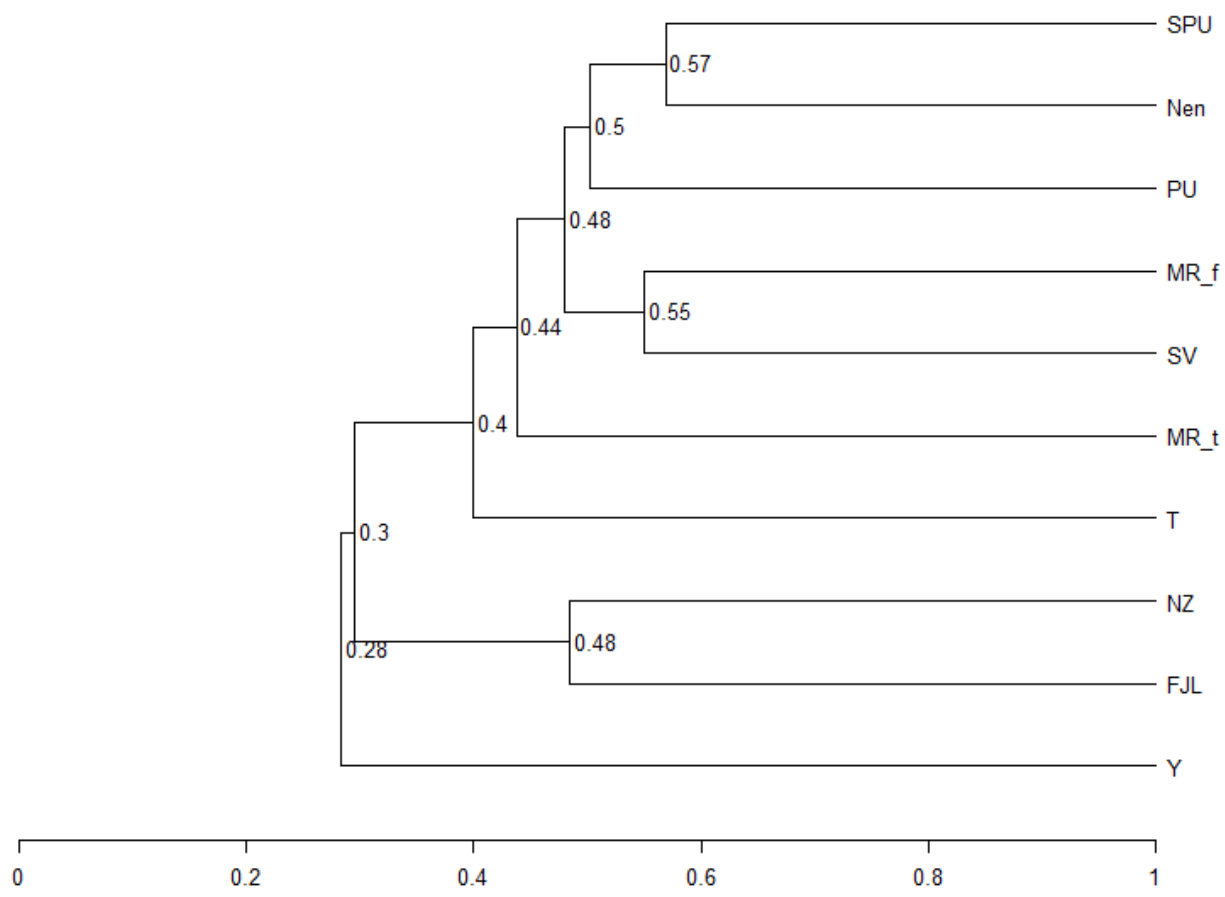

Figure 10. Complete graph of similarity of cyanobacterial flora in some Arctic and sub-Arctic areas (for the clustering, Sørensen index was used to show the mean distance between elements of each cluster (weighted pair group method using arithmetic averaging, numbers on ridges are similarity in percent)). FJL-Franz Josef Land Archipelago, MRt-Murmansk region tundra zone, MRfMurmansk region forest zone, Nen-Nenets AO, NZ-Novaya Zemlya Archipelago, PU—Polar Urals, SV—Svalbard Archipelago, T-Taymyr peninsula, Y-Yamal peninsula.

\section{Conclusions}

We investigated the diversity of cyanobacteria in Ochenyrd ridge for the first time. We noted a relatively high species diversity of cyanobacteria in the northern part of the Polar Urals. In the northern part of the Polar Urals, we identified 37 species of cyanobacteria that have never before been documented in the region. A significant number of new species occurrences reflect the potentially high diversity of terrestrial cyanobacteria in this area. Such species richness is due to both many mountain habitat types and geological rock diversity. The identification of many species new to the region indicates that the potential cyanobacterial diversity of the region has not been sufficiently investigated. Based on the spatial distribution, most of the identified species are quite widespread in the Arctic and sub-Arctic. At the same time, we also found species that were not previously recorded in high-latitude regions.

Chroococcus and Gloeocapsa were the most frequently encountered cyanobacterial genera, followed by Aphanocapsa. The most frequently encountered taxa were typically rock and soil inhabitants (Phormidesmis sp., Gloeocapsa violascea, Stigonema minutum, Calothrix parietina, Gloeocapsopsis magma, Nostoc commune).

The list of cyanobacteria common in the Polar Urals includes 179 species. A high similarity between the species composition of the flora in the Polar Urals and other wellstudied Arctic and sub-Arctic territories was notable. The greatest similarity was found between the flora of the neighboring region of the Nenets $\mathrm{AO}$, including the assemblages of the Bolshezemelskaya tundra and the Malozemelskaya tundra.

Funding: This research was funded by the Russian Science Foundation, grant number 21-14-00029 (https: / rscf.ru/project/21-14-00029/, accessed on 1 October 2021). The research was done using large-scale research facilities at the herbarium at the Polar-Alpine Botanical Garden-Institute (KPABG; Kirovsk, Russia) reg. No. 499397. 
Institutional Review Board Statement: Not applicable.

Informed Consent Statement: Not applicable.

Data Availability Statement: Data Availability Statement: the data supporting reported results can be found in a publicly archived dataset of "L" information system https:/ / isling.org/ (accessed on 10 October 2021) or in the previous version "CRIS" by this link http:/ / kpabg.ru/cyanopro/?q=serae d\&field_hernum1_value=\&field_legnum_value_op=contains\&field_legnum_value=\&field_location_ value=Polar+Urals\&field_country_tid=\&field_detdate_value $=\&$ field_detname_tid=\&field_dateleg_v alue $=\&$ field_province_tid=\&field_reserve_tid=\&field_lid_value=\&field_ccc1_value=\&field_ccc2_va lue $=\&$ nid $=\&$ field_type_value $=$ All (accessed on 10 October 2021).

Conflicts of Interest: The author declares no conflict of interest. The funders had no role in the design of the study; in the collection, analyses, or interpretation of data; in the writing of the manuscript; or in the decision to publish the results.

\section{References}

1. Davydov, D.; Patova, E. The diversity of Cyanoprokaryota from freshwater and terrestrial habitats in the Eurasian Arctic and Hypoarctic. Hydrobiologia 2018, 811, 119-138. [CrossRef]

2. Ribeiro, K.F.; Duarte, L.; Crossetti, L.O. Everything Is Not Everywhere: A Tale on the Biogeography of Cyanobacteria. Hydrobiologia 2018, 820, 23-48. [CrossRef]

3. Boyer, S.L.; Johansen, J.R.; Howard, G.L. Phylogeny and genetic variance in terrestrial Microcoleus (Cyanophyceae) species based on sequence analysis of the 16S rRNA gene and associated 16S-23S ITS region. J. Phycol. 2002, 38, 1222-1225. [CrossRef]

4. Strunecky, O.; Raabova, L.; Bernardova, A.; Ivanova, A.P.; Semanova, A.; Crossley, J.; Kaftan, D. Diversity of Cyanobacteria at the Alaska North Slope with Description of Two New Genera: Gibliniella and Shackletoniella. FEMS Microbiol. Ecol. 2020, 96 , fiz189. [CrossRef]

5. Casamatta, D.A.; Vis, M.L.; Sheath, R.G. Cryptic species in cyanobacterial systematics: A case study of Phormidium retzii (Oscillatoriales) using 16S rDNA and RAPD analyses. Aquat. Bot. 2003, 77, 295-309. [CrossRef]

6. Mai, T.; Johansen, J.R.; Pietrasiak, N.; Bohunicka, M.; Martin, M.P. Revision of the Synechococcales (Cyanobacteria) through recognition of four families including Oculatellaceae fam. nov. and Trichocoleaceae fam. nov. and six new genera containing 14 species. Phytotaxa 2018, 365, 1-59. [CrossRef]

7. Davydov, D.; Shalygin, S.; Vilnet, A. New cyanobacterium Nodosilinea svalbardensis sp. nov. (Prochlorotrichaceae, Synechococcales) isolated from alluvium in Mimer river valley of the Svalbard archipelago. Phytotaxa 2020, 442, 61-79. [CrossRef]

8. Voronikhin, N.N. Algae Polar and Northern Urals. Proc. Leningr. Soc. Nat. 1930, 60, 1-71. (In Russian)

9. Yarushina, M.I. Algae of reservoirs of the Polar Urals. In Biological Resources of the Polar Urals; Pashalny, S.P., Ed.; Department of Information and Socio-Political Research of the Yamalo-Nenets Autonomous District: Salekhard, Russia, 2002; Volume 3, pp. 71-77. (In Russian)

10. Yarushina, M.I. Phytoplankton of lakes on the western slope of the Polar Urals. In Biological Resources of the Polar Urals; Pashalny, S.P., Ed.; Department of Information and Socio-Political Research of the Yamalo-Nenets Autonomous District: Salekhard, Russia, 2003; Volume 10, pp. 30-36. (In Russian)

11. Bogdanov, V.D.; Bogdanova, E.N.; Gavrilov, A.L.; Melnichenko, I.P.; Stepanov, L.N.; Yarushina, M.I. Bioresources Aquatic Ecosystems of the Polar Urals; Urals Dep. RAS: Yekaterinburg, Russia, 2004; pp. 1-167. (In Russian)

12. Voloshko, L.N.; Demina, I.V.; Estafiev, A.A.; Illarionov, V.V.; Kolesnikova, A.A.; Kochanov, S.K.; Kulakova, O.I.; Kulikova, K.V.; Kulyugina, E.E.; Loskutova, O.A.; et al. Biodiversity the Polar Urals Ecosystems; Institute of Biology: Syktyvkar, Russia, 2007; pp. 1-252. (In Russian)

13. Patova, E.N.; Demina, I.V. Algae of water bodies of the Polar Urals, not subject to anthropogenic impact. Inland Water Biol. 2008, 1, 58-67. [CrossRef]

14. Novakovskaya, I.V.; Patova, E.N. Algae of mountain tundra soils in the North and Polar Urals. Bull. MOIP. Otd. Biol. 2013, 118, 57-66. (In Russian)

15. Vinokurova, G.V. Phytoepiliton of Lake Bolshoye Shchuchye and associated rivers (Polar Urals). Sci. Bull. YNAO 2017, 94, 11-14. (In Russian)

16. Mitrofanova, E.Y. Phytoplankton of Lake Bolshoye Shchuchye and the rivers of its basin in August 2016. Sci. Bull. Yamalo-Nenets Auton. Okrug. 2017, 1, 55-61. (In Russian)

17. Patova, E.N.; Novakovskaya, I.V. Diversity of soil algae and cyanoprokaryota in terrestrial communities of the Polar and Subpolar Urals. Theor. Appl. Ecol. 2014, 1, 32-34.

18. Patova, E.N.; Novakovskaya, I.V. Soil algae of the Northeastern European Russia. Nov. Sist. Nizshikh Rastenii 2018, 52, 311-353. [CrossRef]

19. Kemmerikh, A.O. Polar Urals; Publishing House "Physical Culture and Sport": Moscow, Russia, 1966; pp. 1-112. (In Russian)

20. Solomina, O.; Ivanov, M.; Bradwell, T. Lichenometric studieson moraines in the Polar Urals. Geogr. Ann. Ser. A Phys. Geogr. 2010, 92, 81-99. [CrossRef] 
21. Golovin, A.A.; Gusev, G.S.; Gushchin, A.V.; Zaikov, V.V.; Kilipko, V.A.; Krinochkin, L.A.; Mezhelovsky, N.V.; Morozov, A.F.; Sirotkina, O.N.; Flerova, K.V. Mineragenic Potential of the Subsoil of Russia; Geokart, Geos: Moscow, Russia, 2013; Volume 1, pp. 1-484. (In Russian)

22. Kulikova, K.V.; Patova, E.N.; Kulyugina, E.E.; Demina, I.V. The study area. In Biodiversity the Polar Urals Ecosystems; Getzen, M.V., Ed.; Institute of Biology: Syktyvkar, Russia, 2007; pp. 10-15. (In Russian)

23. Shiyatov, S.G. Dynamics of Tree and Shrub Vegetationin the Polar Urals under the Impact of Modern Climate Changes; Urals Department RAS: Yekaterinburg, Russia, 2009; pp. 1-215. (In Russian)

24. Komárek, J.; Anagnostidis, K. Cyanoprokaryota 1. Teil: Chroococcales. In Süsswasserflora von Mitteleuropa 19/1; Unaltered, repr., Ettl, H., Gärtner, G., Heynig, G., Mollenhauer, D., Eds.; Spektrum Akademischer Verlag: Heidelberg, Germany, 2008 ; pp. 1-548.

25. Komárek, J.; Anagnostidis, K. Cyanoprokaryota 2. Teil: Oscillatoriales. In Süsswasserflora von Mitteleuropa 19/2; Büdel, B., Gärtner, G., Krienitz, L., Schlager, M., Eds.; Unaltered repr., 2. print; Spektrum Akademischer Verlag: Heidelberg, Germany, 2008; pp. $1-759$.

26. Komárek, J. Cyanoprokaryota 3. Teil: Heterocytous genera. In Süsswasserflora von Mitteleuropa 19/3; Büdel, B., Gärtner, G., Krienitz, L., Schlager, M., Eds.; Springer: Berlin/Heidelberg, Germany, 2013; pp. 1-1133. [CrossRef]

27. Melechin, A.V.; Davydov, D.; Shalygin, S.; Borovichev, E.A. Open information system on biodiversity cyanoprokaryotes and lichens CRIS (Cryptogamic Russian Information System). Bull. MOIP. Otd. Biol. 2013, 118, 51-56. (In Russian)

28. Melekhin, A.V.; Davydov, D.; Borovichev, E.A.; Shalygin, S.S.; Konstantinova, N.A. CRIS-Service for input, storage and analysis of the biodiversity data of the cryptogams. Folia Cryptogam. Est. 2019, 56, 99-108. [CrossRef]

29. Kondratyeva, N.V.; Kovalenko, O.V. A Short Guide to the Types of Toxic Blue-Green Algae; Naukova dumka: Kiev, Ukraine, 1975; pp. 1-80.

30. Nowakowskiy, A.B. Interaction between Excel and statistical package R for ecological data analysis. Vestn. Insituta Biol. Komi Sci. Ural. Branch 2016, 3, 26-33.

31. Geitler, L. Über die Tiefenflora an Lelsen im Lunzer Untersee. Arch. Für Protistenkd. 1928, 62, 96-104.

32. Gaysina, L.A.; Bohunická, M.; Hazuková, V.; Johansen, J.R. Biodiversity of terrestrial cyanobacteria of the South Ural region. Cryptogam. Algol. 2018, 39, 167-198. [CrossRef]

33. Getsen, M.V.; Stenina, A.S.; Patova, E.N. Algoflora of Bolshezemelskaya Tundra in the Conditions of Anthropogenic Pollution; Komi Science Centre Publishers: Syktyvkar, Russia, 1994; pp. 1-148. (In Russian)

34. Davydov, D. Cyanoprokaryota and Their Role in the Process of Nitrogen Fixation in Terrestrial Ecosystems of the Murmansk Region; GEOS: Moscow, Russia, 2010; pp. 1-184. (In Russian)

35. Davydov, D. Terrestrial Cyanoprokaryota of the western part of Khibiny Mountains. Bull. MOIP. Otd. Biol. 2012, 117, 72-77. (In Russian)

36. Davydov, D. Diversity of the Cyanoprokaryota in polar deserts of Innvika cove North-East Land (Nordaustlandet) Island, Spitsbergen. Czech Polar Rep. 2016, 6, 66-79. [CrossRef]

37. Davydov, D. Cyanoprokaryotes of the west part of Oscar II Land, West Spitsbergen Island, Spitsbergen archipelago. Czech Polar Rep. 2017, 7, 94-108. [CrossRef]

38. Davydov, D. Diversity of the Cyanoprokaryota in polar deserts of Rijpfjorden east coast, North-East Land (Nordaustlandet) Island, Spitsbergen. Algol. Stud. 2013, 142, 29-43. [CrossRef]

39. Davydov, D. Diversity of the Cyanoprokaryota of the area of settlement Pyramiden, West Spitsbergen Island, Spitsbergen archipelago. Folia Cryptogam. Est. 2014, 51, 13-23. [CrossRef]

40. Davydov, D. Checklist of cyanobacteria from the European polar desert zone. Botanica 2018, 24, 185-201. [CrossRef]

41. Gorchakovskiy, P.L. The Flora of the High Mountains of the Urals; Nauka: Moscow, Russia, 1975; pp. 1-283. (In Russian)

42. Gorchakovskiy, P.L.; Kuvaev, V.B. Ecological aspects of vertical differentiation of vegetation cover in the boreal highlands. Russ. J. Ecol. 1985, 3, 12-20.

43. Morozova, L.M. The current state of the vegetation cover on the eastern slope of the Polar Urals. Biol. Resour. Polar Ural. 2002, $10,78-89$.

44. Davydov, D. Cyanobacterial diversity of Svalbard Archipelago. Polar Biol. 2021, 44, 1967-1978. [CrossRef] 